\title{
Epidemiologic data of the patients with spinal cord injury: Seven years' experience of a single center
}

\author{
Omurilik yaralanması olan hastaların epidemiyolojik verileri: \\ Tek merkezin yedi yıllık deneyimi \\ İlknur TUĞCU, ${ }^{1}$ Fatih TOK, ${ }^{2}$ Bilge YILMAZ, ${ }^{1}$ Ahmet S GÖKTEPE, ${ }^{1}$ \\ Rıdvan ALACA, ${ }^{1}$ Kamil YAZICIOĞLU, ${ }^{1}$ Haydar MÖHÜR ${ }^{3}$
}

\section{BACKGROUND}

We aimed to present the demographic and epidemiologic data on spinal cord injury (SCI) patients who were rehabilitated at our hospital, to identify high-risk groups and etiological factors, and to evaluate the factors that affect the duration of hospitalization (DOH).

\section{METHODS}

Data on 905 SCI patients treated on an inpatient basis between December 2000 and June 2007 at our hospital were retrospectively evaluated. Patient age, sex, etiology of injury, DOH, neurologic level, and functional grouping were analyzed. Additionally, the effects of age and sex on DOH were evaluated.

\section{RESULTS}

In total, $661(73 \%)$ of the patients were male and $244(27 \%)$ were female. The mean age of the patients was $33.4 \pm 15.0$ years; $51.27 \%$ of the patients were $20-33$ years of age. The mean DOH was $73.6 \pm 49.8$ days. In all, 304 (33.5\%) of the patients were tetraplegic and $601(66.5 \%)$ were paraplegic. Motor vehicle collisions were the most common cause of injury $(n=318,35.1 \%)$, followed by falls from an elevated height ( $\mathrm{n}=170,18.8 \%)$. DOH was significantly higher among the tetraplegia American Spinal Injury Association (ASIA) A-B patients than among the other patients $(\mathrm{p}<0.01)$.

\section{CONCLUSION}

It is clear that most of the SCIs we observed were preventable. Comprehensive identification of the epidemiologic, demographic and pathologic features of SCIs contributes to identifying high-risk groups, thereby making it possible to pay personal and communal attention to precautions for SCIs.

Key Words: Spinal cord injury/etiology/epidemiology.
$\boldsymbol{A M A C}$

$\mathrm{Bu}$ çalışmada, hastanemizde rehabilite edilmiş omurilik yaralanması olan hastaların demografik ve epidemiyolojik verilerinin sunulması, yüksek risk gruplarının ve etyolojik faktörlerinin belirlenmesi ve hastanede yatış süresine etki eden faktörlerin değerlendirilmesi amaçlanmıştır.

\section{GEREÇ VE YÖNTEM}

Aralık 2000 ile Haziran 2007 yılları arasında hastanemizde yatarak tedavi görmüş 905 hastanın verileri retrospektif olarak incelendi. Hastaların yaşları, cinsiyetleri, yaralanma etyolojisi, hastanede yatış süresi, nörolojik seviye ve fonksiyonel grupları analiz edildi. Hastanede yatış süresini etkileyen faktörler değerlendirildi.

\section{BULGULAR}

Hastaların 661'i (\%73) erkek, 244’̈̈ (\%27) kadındı. Orta-

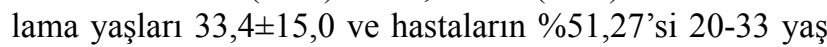
arasındaydı. Hastanede yatış süresi ortalama $73.6 \pm 49.8$ gündü. Hastaların 304'ü $(\% 33,5)$ tetraplejik, 601'i $(\% 66,5)$ paraplejikti. Motorlu araç çarpışmaları kazaların en sık nedeniydi ( $n=318, \% 35,1)$, bunu yüksekten düşme $(n=170$, $\% 18.8$ ) takip etti. Tetrapleji ASIA (American Spinal Injury Association) A-B hastaların yatış süresi diğer hastalardan anlamlı derecede daha fazlayd $1(\mathrm{p}<0,01)$.

\section{SONUÇ}

Omurilik yaralanmalarının çoğu önlenebilir nedenlerden kaynaklanmıştı. Omurilik yaralanmalarının epidemiyolojik, demografik ve patolojik özelliklerinin anlaşılması yüksek risk gruplarının berirlenmesi, yaralanmayı öneleycek bireysel ve toplumsal önlemlerin alınmasına katkı sağlayacaktır.

Anahtar Sözcükler: Omurilik yaralanması/etyoloji/epidemiyoloji.

\footnotetext{
${ }^{1}$ Department of Physical Medicine and Rehabilitation, Gulhane Military Medical Academy, Turkish Armed Forces Rehabilitation Center, Ankara; ${ }^{2}$ Physical Medicine and Rehabilitation Service, İskenderun Military Hospital, Iskenderun; ${ }^{3}$ Department of Physical Medicine and Rehabilitation, Gazi University Faculty of Medicine, Ankara, Turkey.
} 
Spinal cord injuries (SCIs) are rarely seen, but are associated with devastating physical psychological and economic consequences. These injuries are usually seen in young persons of productive age. ${ }^{[1]} \mathrm{SCIs}$ are among the most important causes of disability, morbidity, mortality, and economic loss. ${ }^{[2]}$

Rehabilitation of SCI patients requires lifetime care and a multidisciplinary rehabilitation that addresses the associated functional, physiological, social, and economic problems. The aim of rehabilitation is to help patients regain as much of their pre-injury productivity as possible, with medical, social, occupational, and physiological support.

The purpose of sufficient health support and precaution from SCI is to reduce to a minimum the incidence and effects of SCI. SCIs also occur due to accidents and carelessness, as with most other injuries; thus, epidemiologic and demographic studies are important for identifying risk groups and the factors that cause injury. Nonetheless, epidemiological data on SCI in Turkey are insufficient. One of the few such studies reported an annual incidence of SCI in Turkey as 12.7/1,000,000. ${ }^{[3]}$ The incidence of SCI in developed countries was reported as 6-56/1,000,000, with an annual prevalence in the United States estimated at 250,000. ${ }^{[4,5]}$

The present study aimed to present the demographic and epidemiologic data on SCI patients who were rehabilitated in our hospital, to identify high-risk groups and etiological factors, and to evaluate the factors that affect the duration of hospitalization (DOH).

\section{MATERIALS AND METHODS}

Data on patients who were treated on an inpatient basis between December 2000 and June 2007 at the Turkish Army Forces Rehabilitation Center for Acute Care and Spinal Cord Injury Rehabilitation Department were scanned. In all, the records of 905 SCI patients who were treated on an inpatient basis in our hospital during this time were retrospectively analyzed.

Patient age at the time of injury, sex, injury etiology, DOH, neurologic level, and functional grouping were analyzed. The American Spinal Injury Association (ASIA) classification was used to determine the neurologic level and functional grouping; patients were classified into the following three functional groups: 1. Tetraplegia ASIA A-B; 2. Paraplegia ASIA A-B; 3. Tetraplegia and paraplegia: ASIA C-D-E.

In determining DOH, ASIA neurologic level and functional grouping for patients who were hospitalized more than once, data from the first hospitalization were used. Additionally, the effects of age, sex and functional grouping on DOH were statistically evaluated. The Statistical Package for the Social Sciences (SPSS) v.16.0 for Windows was used for statistical analysis.

\section{RESULTS}

In total, $661(73 \%)$ of the patients were male and $244(27 \%)$ were female. The mean age of the patients was $33.4 \pm 15.0$ years (range: $3-83$ years). In all, $51.27 \%$ of the patients were $20-33$ years of age and $70.02 \%$ were $15-44$ years of age (Table 1 ). The mean DOH was $73.6 \pm 49.8$ days (range: $3-424$ days).

Injury etiology analysis showed that motor vehicle collisions (while inside the vehicle) (IMVC) were the most common cause of injury $(\mathrm{n}=318,35.1 \%)$, followed by fall from a height $(\mathrm{FFH})(\mathrm{n}=170,18.8 \%)$, and gunshot wounds $(\mathrm{GW})(\mathrm{n}=110,12.2 \%)$. Injury etiologies are presented in Table 2.

Among the patients, 304 (33.5\%) were tetraplegic

Table 1. Age distribution of the patients

\begin{tabular}{lcc}
\hline Age (years) & $\mathrm{n}$ & $\%$ \\
\hline $0-10$ & 14 & 1.54 \\
$11-14$ & 12 & 1.32 \\
$15-19$ & 64 & 7.07 \\
$20-33$ & 464 & 51.27 \\
$34-44$ & 151 & 16.68 \\
$45-60$ & 142 & 15.69 \\
$61-83$ & 58 & 6.40 \\
\hline
\end{tabular}

Table 2. Distribution of patients according to neurologic level, ASIA classification, functional grouping, and etiology

\begin{tabular}{lcc}
\hline & $\mathrm{n}$ & $\%$ \\
\hline Tetraplegia & 304 & 33.5 \\
Paraplegia & 601 & 66.5 \\
C3-C8 & 304 & 33.5 \\
T1-T12 & 457 & 50.5 \\
L1-L4 & 144 & 16 \\
ASIA-A & 485 & 53.6 \\
ASIA-B & 158 & 17.5 \\
ASIA-C & 135 & 14.9 \\
ASIA-D & 122 & 13.5 \\
ASIA-E & 5 & 0.6 \\
Functional group 1 & 197 & 21.8 \\
Functional group 2 & 256 & 28.3 \\
Functional group 3 & 452 & 49.9 \\
IMVC & 318 & 47.5 \\
FFH & 170 & 18.8 \\
GW & 110 & 12.2 \\
TM & 65 & 7.2 \\
DSW & 42 & 4.6 \\
Tumors & 41 & 4.5 \\
OMVC & 40 & 4.4 \\
EHW & 27 & 3.0 \\
KW & 2 & 0.2 \\
Other etiologies & 90 & 9.9 \\
Total & 905 & 100 \\
\hline
\end{tabular}




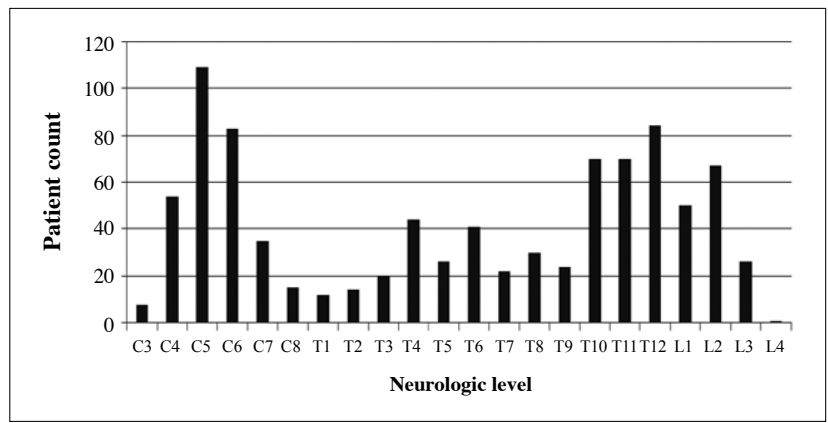

Fig. 1. Patient distribution according to neurologic level.

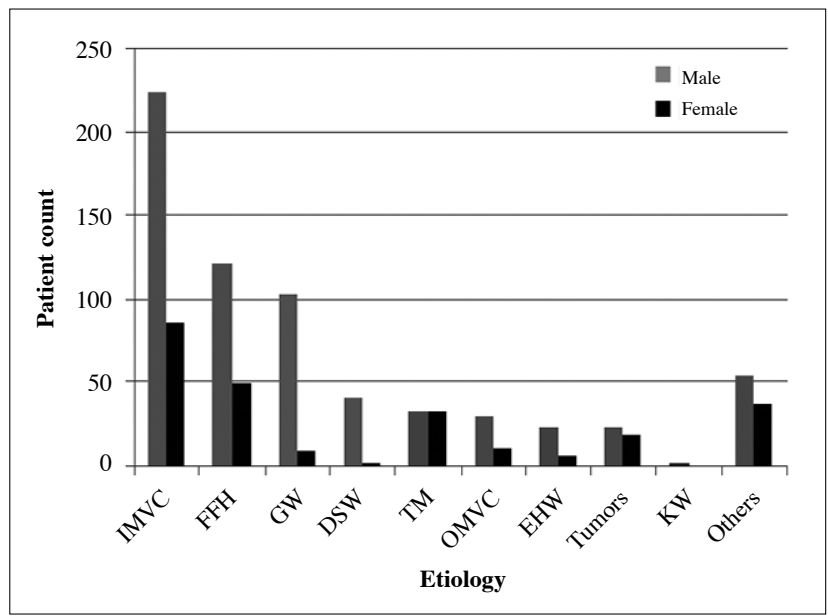

Fig. 2. Distribution of male and female SCI patients according to etiology. IMVC: Motor vehicle collision (inside the vehicle); FFH: Fall from a height; GW: Gunshot wound; DSW: Diving into shallow water; OMVC: Motor vehicle collision (outside the vehicle); EHW: Exposure to high weight; KW: Knife wound.

and $601(66.5 \%)$ were paraplegic. Distribution of patients according to ASIA functional grouping was as follows:

1. Tetraplegia, ASIA A-B: 197 (21.8\%) patients.

2. Paraplegia, ASIA A-B: 256 (28.3\%) patients.
3. Tetraplegia and paraplegia, ASIA C-D-E: 452 (49.9\%) patients.

The distribution of patients according to ASIA neurologic level and functional grouping are presented in Table 2. The most common neurologic level was cervical-5 $(\mathrm{n}=109)$ (distribution is presented in Fig. 1), followed by thoracic-12 $(n=84)$, cervical- $6(n=83)$, and thoracic-10 and thoracic-11 ( $\mathrm{n}=70$ patients).

The distribution of neurologic level among male and female patients is presented in Figure 2. IMVC was the most common etiology among both sexes, followed by FFH. While GW was the third most common etiology among the male patients (15.4\%), it was the sixth most common etiology among the females (3.3\%). IMVC was the cause of SCI in 5 patients in 2000,41 patients in 2001, 45 patients in 2002, 56 patients in 2003, 70 patients in 2004, 57 patients in 2005, 54 patients in 2006 , and 30 patients in 2007 . The small number of patients injured due to IMVC in 2000 and 2007 might be attributed to the dates of the study period, which ran from December 2000-June 2007.

Neurologic levels according to the etiology are presented in Table 3. With reference to this table, cervical levels were common in cases of diving into shallow water (DSW) and IMVC, and thoracic levels were common in cases of FFH, GW, knife wounds (KW), and exposure to heavy weight (EHW).

When we separated the SCI patients into etiological subgroups, the mean age at injury among 110 patients injured due to $\mathrm{GW}$ was $26.3 \pm 8.1$ years (range: $13-52$ years). Age distribution of the GW-injured patients is presented in Figure 3. The densest age accumulation among the GW-injured patients was between 20 and 30 years, with $81(73.6 \%)$ patients in this age group.

The mean age of the patients injured due to IMVC was $30.6 \pm 12.3$ years (range: $3-70$ years) and the age distribution is presented in Figure 4. The most common age group among the IMVC-injured patients was

Table 3. The relationship between SCI etiology and neurologic level

\begin{tabular}{|c|c|c|c|c|}
\hline \multirow{2}{*}{$\frac{\text { SCI etiology }}{\text { IMVC }}$} & \multicolumn{4}{|c|}{ The 4 most common neurologic levels } \\
\hline & C-5 (13.2\%) & C-6 (9.7\%) & $\mathrm{T}-11(8.5 \%)$ & C-4 (7.9\%) \\
\hline FFH & $\mathrm{T}-12(17.1 \%)$ & $\mathrm{T}-10(10.0 \%)$ & $\mathrm{T}-11(10.0 \%)$ & C-5 (8.2\%) \\
\hline GW & $\mathrm{T}-12(14.5 \%)$ & $\mathrm{T}-10(11.8 \%)$ & L-1 $(9.1 \%)$ & $\mathrm{T}-4(9.1 \%)$ \\
\hline Transverse myelitis & C-5 (15.4\%) & L-2 (13.8\%) & C-6 (12.3\%) & L-1 $(9.2 \%)$ \\
\hline DSW & C-6 $(35.7 \%)$ & C-5 $(33.3 \%)$ & C-4 $(19.0 \%)$ & C-7 $(7.1 \%)$ \\
\hline Tumors & C-5 $(9.8 \%)$ & $\mathrm{T}-12(9.8 \%)$ & L-2 $(9.8 \%)$ & $\mathrm{T}-6(9.8 \%)$ \\
\hline OMVC & C-6 $(15 \%)$ & C-5 (12.5\%) & $\mathrm{T}-10(10.0 \%)$ & $\mathrm{T}-12(10.0 \%)$ \\
\hline EHW & $\mathrm{T}-11(22.2 \%)$ & T-10 (11.1\%) & L-2 (11.1\%) & C-5 (11.1\%) \\
\hline KW & $\mathrm{T}-9(50 \%)$ & $\mathrm{T}-11(50 \%)$ & & \\
\hline Others & C-6 $(14.4 \%)$ & C-5 $(13.3 \%)$ & L-2 (13.3\%) & $\mathrm{T}-10(8.9 \%)$ \\
\hline
\end{tabular}

IMVC: Motor vehicle collision (inside the vehicle); FFH: Fall from a height; GW: Gunshot wound; DSW: Diving into shallow water; OMVC: Motor vehicle collision (outside the vehicle); EHW: Exposure to heavy weight; KW: Knife wound. 


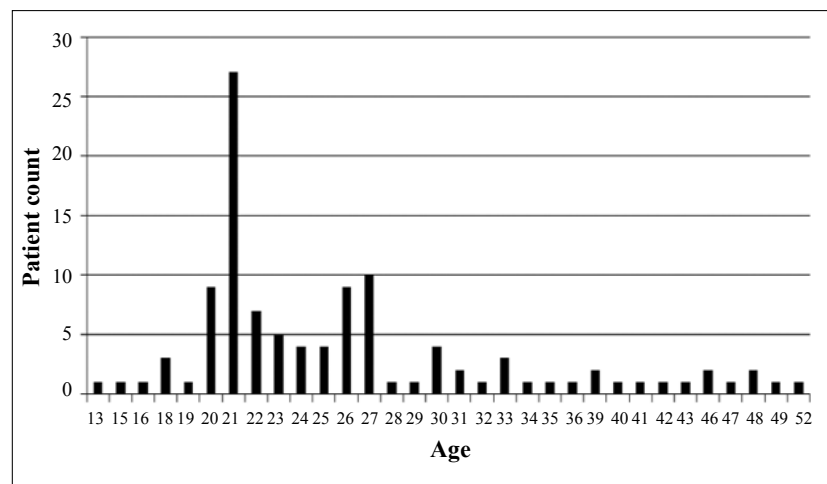

Fig. 3. Distribution of gunshot wound (GW) SCI patients according to age.

19-45 years of age $(n=259,81.4 \%)$. Age distribution was more heterogeneic among patients injured due to MVCs (outside of the vehicle, OMVCs), and the highest density was between 20 and 30 years of age (Fig. 5).

The mean age of the 42 patients injured due to DSW was 23.9 \pm 8.8 years (range: $13-64$ years), and 33 of these patients were 17-28 years of age. All the patients injured due to DSW were tetraplegic. The neurologic level in 14 of these patients was cervical-5, versus cervical- 6 in 15 patients; $69 \%$ of the patients injured due to DSW had a neurologic level of cervical-5 and 6 .

Analysis of the factors that affected DOH among the
SCI patients showed that there was no meaningful correlation between patient age $(\mathrm{p}=0.41)$ or $\operatorname{sex}(\mathrm{p}=0.36)$ and DOH. Post-hoc Bonferroni testing was applied after determining high significance $(p<0.0001)$ in variance analysis in order to evaluate the efficacy of functional groups on $\mathrm{DOH}$. The results showed that there was a statistically significant difference $(p<0.0001)$ between the effect of functional group 1 and that of functional groups 2 and 3 on $\mathrm{DOH}$, whereas the difference $(p=0.27)$ between the effect of functional groups 2 and 3 on $\mathrm{DOH}$ was not significant (DOH according to functional groups is presented in Table 2).

When we investigated the effects of etiology on $\mathrm{DOH}$, we grouped GW and $\mathrm{KW}$ under the heading "wounds", and in the same way grouped IMVC and OMVC under "MVC"; however, other traumatic causes were grouped as "traumatic other", and other etiologies without trauma were grouped as "non-traumatic". The wound group included 112 patients with a mean DOH of $65.9 \pm 49$ days (range: 6-310 days), the MVC group included 358 patients with a mean DOH of $80.9 \pm 53.4$ days (range: $3-316$ days), the traumatic other group included 239 patients with a mean $\mathrm{DOH}$ of 72 \pm 38.1 days (range: $3-195$ days), and the non-traumatic group included 196 patients with a mean DOH of $66.4 \pm 54.2$ days (range: 6-424 days). After this grouping, we determined high significance $(p<0.002)$ in order to evaluate group effects on $\mathrm{DOH}$ with vari-

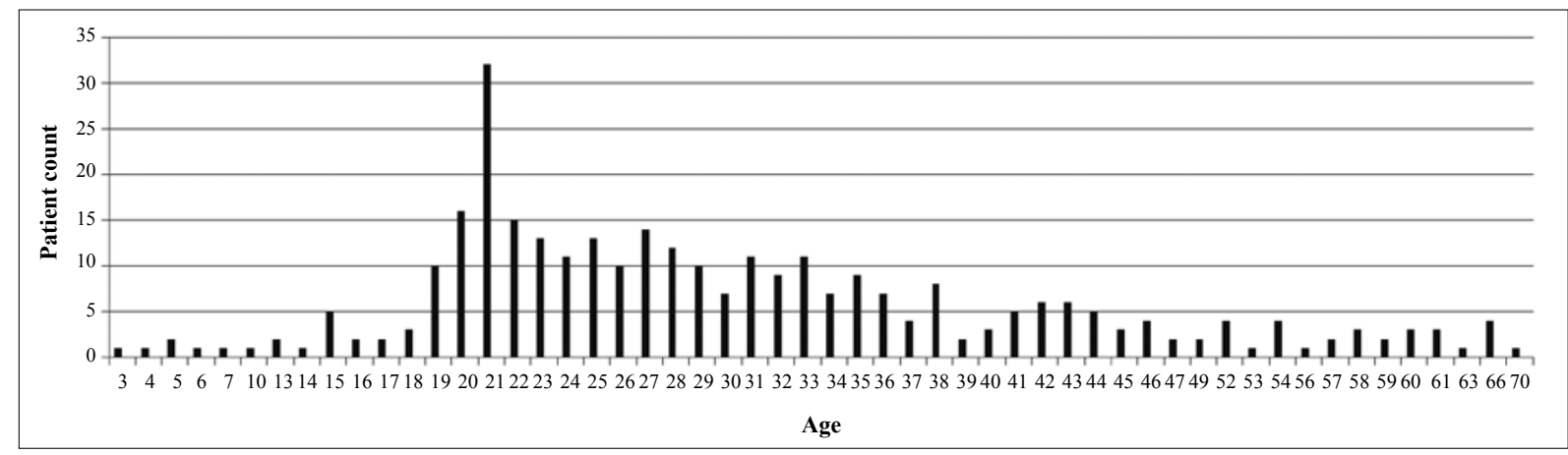

Fig. 4. Distribution of motor vehicle collision (inside the vehicle) (IMVC) SCI patients according to age.

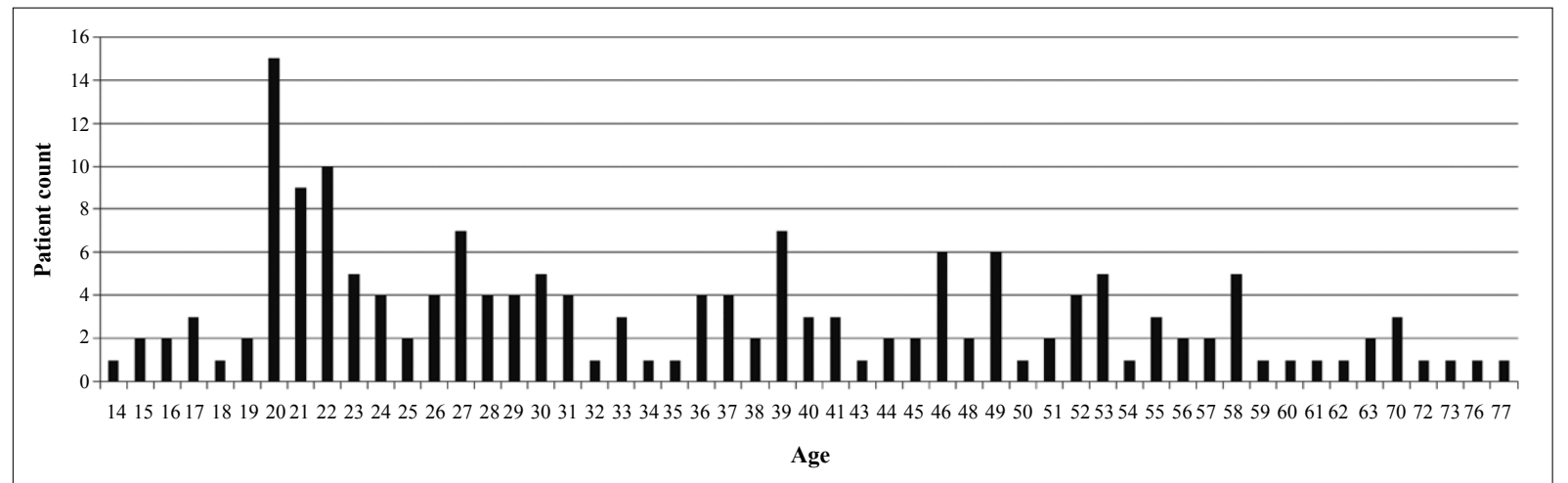

Fig. 5. Distribution of fall from height (FFH) SCI patients according to age. 
ance analysis. Based on post-hoc Bonferroni testing, $\mathrm{DOH}$ in the MVC group was significantly longer than in the wound $(p=0.03)$ and non-traumatic $(p=0.006)$ groups; however, there was no significant difference in $\mathrm{DOH}$ between the traumatic other group and the MVC group ( $p=0.19)$. Furthermore, there was no significant difference in $\mathrm{DOH}$ between the three groups except MVC ( $\mathrm{p}>0.5)$.

\section{DISCUSSION}

Spinal cord injury (SCI) is an important problem due to its associated physical, psychological, social, and economic consequences. We think that comprehensive identification of the epidemiologic, demographic and pathologic features of SCI contributes to identifying high-risk groups, thereby making it possible to pay personal and communal attention to precautions for SCIs. The present study presents epidemiologic data on SCI patients who were treated on an inpatient basis at our hospital, which is a tertiary care center, from December 2000 to June 2007.

Motor vehicle collision (MVC) was the most common etiology in the present study, followed by FFH, as in many other studies; $;^{[3,6-11]}$ however, the ratio of SCI etiologies varies according to country. For example, O'Connor et al. ${ }^{[12]}$ reported that they did not observe any SCIs due to GW or KW in Ireland due to Ireland's strict weapons control laws. The high incidence of SCI due to GW in the young population in the present study was probably due to the fact that our hospital primarily serves veterans; however, SCIs due to GW among females and civilians calls into question the efficacy of Turkish laws related to obtaining and carrying guns.

A bimodal age distribution was observed in the present study; $51.27 \%$ of the patients were $20-33$ years of age. MVC was the first common etiology in this age group, as it was among the other age groups. O'Connor et al. ${ }^{[12]}$ concluded that higher SCI incidence rates due to $\mathrm{MVC}$ are seen in less developed countries with poor road safety and a primarily agricultural economy. Gwynedd et al. ${ }^{[13]}$ observed a relationship between traffic accidents and traffic laws, and emphasized that if the incidence of traffic accidents could not be reduced, the incidence of SCI might be reduced with effective first aid, evacuation from the vehicle and transport to hospital. During these operations, SCI and traumatic brain injury should be remembered firstly.

Burke et al. ${ }^{[8]}$ reported that MVC caused $35 \%$ and FFH caused $31 \%$ of SCIs, whereas in the present study, IMVC and OMVC caused $51.1 \%$ and FFH caused $18.8 \%$ of SCIs. These results indicate that Turkish traffic laws and first aid operations must be critically reviewed and modified. In the present study, we determined that 70 patients were injured due to MVC in
2004, followed by 57 in 2005, and 56 in 2003; however, it was reported that there were 455,667 accidents in $2003,537,384$ in $2004,621,183$ in $2005,728,756$ in 2006, and 825,583 in 2007 (Report of Traffic Accidents, Turkish Republic General Directorate of Highways, October 2007). ${ }^{[14]}$

In the present study, C-5 was the most common neurological level (Fig. 1). This result is compatible with Da Burkes' findings; however, Gur et al. reported that the most frequent neurological level was L-1 and Karacan et al. reported that the most frequent neurological level was $\mathrm{T}-12 .{ }^{[3,4,8]}$ We determined that C-5 was the most common neurological level in patients injured due to IMVC, tumors and transverse myelitis and the second most common neurologic level among those injured due to OMVC, DSW and other injuries (Table 3).

The present study's results show that DOH was longer among the patients injured due to IMVC and OMVC than among the other patients. This situation can be explained with multiple traumas due to traffic accidents. Moreover, we observed that $\mathrm{DOH}$ in the traumatic group was longer than in the non-traumatic group.

The present study has a few limitations. The study was not an incidence study and such studies have not been conducted recently in Turkey. We did not collect any data concerning whether passengers in traffic accidents used safety belts, if drivers had used alcohol, or where individuals were sitting in the vehicle at the time of the accident. Another limitation was the lack of data collection concerning the circumstances associated with FFH (work accident, fall from a tree, suicide attempt, etc.). Lack of information about stabilization operations and factors affecting $\mathrm{DOH}$ were other limitations.

It is clear that most SCIs we observed were preventable. We think etiologies such as IMVC, OMVC and GW can be prevented with amended traffic laws, changes to the procedures for obtaining and carrying guns, and increasing audits and educational programs. On the other hand, etiologies like FFH and DSW are also preventable with a high education level and social consciousness, and with a greater mass of people learning how to administer first aid to injured patients after accidents. SCI studies that aim to determine costeffective preventative measures are needed, as is critical analysis of the risk factors and of how, when, and where SCIs occur. Moreover, epidemiological data on SCIs and multi-centered studies are warranted.

\section{REFERENCES}

1. Devivo MJ. Epidemiology of traumatic spinal cod injury. In: Kirshblum SC, Campagnolo D, DeLisa JE, editors. Spinal cord medicine. Phidelphia: Lippincott Williams and Wilkins; 
2002. p. 69-81.

2. DeVivo MJ. Causes and costs of spinal cord injury in the United States. Spinal Cord 1997;35:809-13.

3. Karacan I, Koyuncu H, Pekel O, Sümbüloglu G, Kirnap M, Dursun H, et al. Traumatic spinal cord injuries in Turkey: a nation-wide epidemiological study. Spinal Cord 2000;38:697-701.

4. Gur A, Kemaloglu MS, Cevik R, Sarac AJ, Nas K, Kapukaya A, et al. Characteristics of traumatic spinal cord injuries in south-eastern Anatolia, Turkey: a comparative approach to 10 years' experience. Int J Rehabil Res 2005;28:57-62.

5. Pickett W, Simpson K, Walker J, Brison RJ. Traumatic spinal cord injury in Ontario, Canada. J Trauma 2003;55:1070-6.

6. van Asbeck FW, Post MW, Pangalila RF. An epidemiological description of spinal cord injuries in The Netherlands in 1994. Spinal Cord 2000;38:420-4

7. Prasad VS, Schwartz A, Bhutani R, Sharkey PW, Schwartz ML. Characteristics of injuries to the cervical spine and spinal cord in polytrauma patient population: experience from a regional trauma unit. Spinal Cord 1999;37:560-8.

8. Burke DA, Linden RD, Zhang YP, Maiste AC, Shields CB. Incidence rates and populations at risk for spinal cord injury: A regional study. Spinal Cord 2001;39:274-8.

9. Dixon GS, Danesh JN, Caradoc-Davies TH. Epidemiology of spinal cord injury in New Zealand. Neuroepidemiology 1993; 12:88-95.

10. Biering-Sørensen E, Pedersen V, Clausen S. Epidemiology of spinal cord lesions in Denmark. Paraplegia 1990;28:10518.

11. Gjone R, Nordlie L. Incidence of traumatic paraplegia and tetraplegia in Norway: a statistical survey of the years 1974 and 1975. Paraplegia 1978;16:88-93.

12. O’Connor RJ, Murray PC. Review of spinal cord injuries in Ireland. Spinal Cord 2006;44:445-8.

13. Pickett GE, Campos-Benitez M, Keller JL, Duggal N. Epidemiology of traumatic spinal cord injury in Canada. Spine (Phila Pa 1976) 2006;31:799-805.

14.http://www.kgm.gov.tr/kaza2k.asp. 